\title{
Willingness to travel to avoid conflicts in Danish forests
}

Bakhtiari, Fatemeh; Jacobsen, Jette Bredahl; Jensen, Frank Søndergaard

Published in:

Urban Forestry \& Urban Greening

DOI:

10.1016/j.ufug.2014.08.004

Publication date:

2014

Document version

Early version, also known as pre-print

Citation for published version (APA):

Bakhtiari, F., Jacobsen, J. B., \& Jensen, F. S. (2014). Willingness to travel to avoid conflicts in Danish forests.

Urban Forestry \& Urban Greening, 13(4), 662-671. https://doi.org/10.1016/j.ufug.2014.08.004 
This is a pre-print of the paper later published as: Bakhtiari, F., Jacobsen, J.B., Jensen, F.S., 2014. Willingness to travel to avoid conflicts in Danish forests. Urban Forest \& Urban Greening 13(4), 662-671. http://dx.doi.org/doi:10.1016/j.ufug.2014.08.004

\title{
Willingness to Travel to avoid recreation conflicts in Danish forests
}

\author{
Fatemeh Bakhtiari $^{{ }^{*}}$, Jette Bredahl Jacobsen ${ }^{1}$, Frank Søndergaard Jensen ${ }^{2}$
}

\begin{abstract}
1-Department of Food and Resource Economics \& Centre for Macroecology, Evolution and Climate, University of Copenhagen, Rolighedsvej 23, DK-1958 Frederiksberg C, Denmark.

2- Department of Geosciences and Natural Resource Management, University of Copenhagen, Rolighedsvej 23, DK-1958 Frederiksberg C, Denmark.
\end{abstract}

*Corresponding author. E-mail:fba@ifro.ku.dk; phone: +4552464054

\begin{abstract}
Conflicts among forest visitors have direct effects on the quality of a recreational experience. As the number of visitors to forests close to residential areas increases, as well as the number of different activities, so does the potential for perceived conflicts. According to the literature, expanding knowledge of conflict characteristics and their causes is important for recreation planners and managers who aim to reduce conflicts.

In the present study, different forest user groups were identified and categorised according to their pursued activities, and for each group causes of conflict were identified. Furthermore, a choice experiment was constructed to estimate the distance visitors are willing to travel to encounter few visitors as opposed to many visitors, and thereby potentially experience fewer conflicts. Comparing marginal willingness to travel (WTT) of different user groups suggests that some groups have a WTT further than the average to reach a forest with 'Few' visitors. The average WTT to reach a forest area with 'Few' visitors is $6 \mathrm{~km}$ per visit. 'Mountain bikers, 'Peace and nature lovers' and
\end{abstract}


'Horse riders' are willing to travel $4 \mathrm{~km}$ more than the average per visit to reach a less crowded forest. At the other end, we find that people who are doing physical exercises are willing to travel 2 $\mathrm{km}$ less than the average to reach a less crowded forest.

Key words: Willingness to travel, recreation conflicts, forest users, (perceived) conflicts, crowding

\section{Introduction}

\section{1-1 Problem statement}

There is a current political focus on encouraging people to visit forest areas to pursue recreational activities which, among other things, is assumed to increase health and wellbeing (Olsen et al., 2013). For example, a correlation study in Sweden by Grahn and Stigsdotter (2003) suggests a lower rate of sickness reporting caused by stress among people who visit forests more often. An epidemiological correlation study implemented in the Netherlands by Maas et al. (2006) illustrated that residents in neighbourhoods with rich green space are likely to, on average, enjoy a better general health. As many people live in cities, an already intensive recreational use of the areas may be even more intensive with the encouragement of increased activity. This may cause problems in terms of crowding (Absher and Lee, 1981; Shelby et al., 1989, Hall and Cole, 2007), which also can also increase the risk of conflicts. Therefore an issue faced by managers is how to design forests and other green spaces so as to distribute the recreational use spatially. This paper contributes by first; investigate the existence of potential conflict among different forest user group which identifies who disturbs whom, and to what extent. Secondly, we investigate how much farther people are willing to travel (WTT) to avoid meeting (too) many forest visitors and thereby avoid potential conflicts? Third we investigate if some user groups more willing to travel further than others? 
Currently in Denmark afforestation is closely linked to an increasingly urban society. This development is concerned with the occurrence of a new urban condition in which the city can no longer be considered as an established area surrounded by open countryside but is increasingly becoming part of growing urban regions comprising both the city and countryside (Clemmensen et al., 2010). According to Konijnendijk this means that forestry must take other disciplines including urbanism and landscape architecture (2008). A trend can be seen that the forests situated nearby residential areas are becoming more and more attractive sites for (more diverse) recreational activities (Jensen, 2012b). This illustrates the increasing importance of local (urban) outdoor recreation for Danes. Increasing the number (and diversity) of visitors will increase the probability of crowding and encounter rates which reduce the quality of an outdoor experience (Absher and Lee, 1981; Shelby et al., 1989; Kleiber, 2001; Hall and Cole, 2007). The presence of conflicts is one indicator of the social carrying capacity in recreation and tourism settings being exceeded.

In Denmark, the average adult citizen visits forests 33-38 times per year (not adjusted for exaggeration) for recreational purposes (Jensen and Koch, 2004; Jensen, 2012a). Most previous studies show that the Danish population will ask for significant compensation for reductions in their current access rights to forest and other habitats (Jacobsen et al., 2012). Denmark is characterised by a relatively high number of inhabitants on a relatively small and intensively exploited land area; 5.4 million inhabitants on $43,000 \mathrm{~km} 2$ of which $11 \%$ is forest and $10 \%$ constituted by other nature areas (Danish Forest and Nature Agency, 2002). The forests in the area are dominated by broadleaved tree species and can predominantly be characterized as urban forests within a mixed landscape of agriculture. In the study area, state forest districts and many private forest districts have established numerous facilities for public use such as playgrounds, simple camp sites, information boards, visitor centres, barbecue sites, bird watching towers, etc. Each year, more than 
500,000 people in total participate in a range of activities organized by forest rangers, and nature schools and forest kindergartens are increasingly popular (Danish Forest and Nature Agency, 2002). According to Jensen (1999), in Danish forests different types of forest visitors exist with presumably different needs. Among the pursued activities, approximately two-thirds of forest visitors had gone for walks during their visits. Just over half had "enjoyed nature", while exercising, and riding and walking the dog were activities selected by $10-15 \%$ of the visitors. Relatively few visitors to the forest (1-2\%) engaged in activities such as riding, hunting, or fishing (Jensen and Koch, 2004). Bell et al. (2007) shows that in densely populated countries, out-group conflicts tend to dominate (e.g., Belgium, Denmark, and Germany). This may happen since there are often many (different) user groups competing for space (Vedel et al., 2009).

Recently the Danish Nature Agency has reported conflicts among different forest users (Søderlund, 2012) at several places in the state forests. Sharp nails have been hammered into tree roots on mountain biking tracks in an attempt to discourage bikers. Not only do metal nails present a high risk of puncture and throw, it may also present a danger to both forest animals and people as well. The set-up of ropes across mountain biker routes has also been reported. The Agency reports forest user complaints of mountain bikers and group cyclists who often shout to the other cyclists and warn when there are walkers along the path. This disturbs people walking in the forest who are seeking peace and quiet (Stenar, 2012). Consequently, the agency has in cooperation with The Danish Outdoor Council and the Sports Confederation of Denmark in 2014 launched an awareness campaign for proper behaviour in the nature ('Nice by nature'/'Flink af natur') - illustrating an increased need of knowledge for forest planners and managers to be able to handle trends in (urban) outdoor recreation in tune with forest user preferences. 
There has been a recent political focus on improving the quality of recreation, e.g. by avoiding conflicts, out-group conflicts in particular. This has been done by establishing trails targeted for different user groups in selected areas (Danish Forest and Nature Agency, 2009; Vedel, 2010). But the individual is also likely to avoid conflicts. Some visitors are more averse to perceived conflicts than others, and one coping strategy for recreationists is to avoid crowded forests, and thereby potential conflicts. For example, forest user groups who feel disturbed may shift the time of visit from weekends to weekdays or off-peak time periods (e.g. Hammitt and Patterson, 1991). Recreationists may also decide to visit an alternative location either within the same recreational area (i.e. intra-site displacement) or visit completely different recreation settings (i.e. inter-site displacement) (e.g. Hall and Shelby, 2000; Johnson and Dawson, 2004). If they do so, they may be willing to travel further to avoid potential conflicts. Thus, the distance people are willing to travel to avoid conflicts may be an indicator of how important they perceive the conflict to be, and thus the travel cost may even be an indicator of the economic value of it.

Several studies have focused on the crowding and conflict perception in various tourism and recreational areas, in countries such as the United States, Australia, and New Zealand (Shelby et al., 1989; Vaske et al., 1996; Manning, 1999; Vaske and Donnelly; 2002; Inglis et al., 1999). In Europe, there has been relative little focus on the relationship between crowding and conflicts, despite the fact of a dense population in many areas. Therefore the current study contribute by empirical evidence of the preferences of visitors and willingness to travel to avoid crowding and thereby the potential for conflicts. 


\section{1-2 Definition of crowding and conflict}

Conflicts in recreation have been categorised into two classifications: (i) interpersonal conflicts which occur as a result of goal interference when one or more persons disturb or affect a goal of another person, and (ii) social value conflicts which mainly happen as a result of contradictory views about the social acceptability of different behaviours in specific recreation settings (Vaske et al., 2007). According to the second classification, conflicts do not necessarily require people to be in physical proximity to one another. Therefore, conflicts can be two different constructs: actual conflicts and perceived conflicts. Perceived conflicts can be felt due to different psychological, social and environmental factors. Investigating perceived conflicts would be a required step in conflict management for reaching a balanced status quo (Jenkins and Pigram, 2013). Therefore, this study aims at investigating the presence and causes of perceived conflicts.

The presence of many other people can exacerbate the negative feeling of potential conflicts - when experienced as crowding. Research has documented that high visitor density leads to high encounter rates which can result in crowding and reduce the quality of an outdoor experience (Absher and Lee, 1981; Shelby et al., 1989; Hall and Cole, 2007). Crowding is a negative evaluation of a particular density of people in an area (Stokols, 1972; Rapoport, 1975; Kuss et al., 1990). Arnberger and Haider (2005) state that crowding is an individual's subjective experience. Jacob and Schreyer (1980) and Owens (1985) attempt to distinguish conflict and crowding from a goal oriented social and psychological perspective. According to them, social interrelationships and differences among users is the root of the problem rather than the actual physical influences they might have on one 
another. According to Owens (1985) crowding is considered as an instant reaction to present conditions and therefore is temporary.

Conflicts are more persistent and stable beyond a particular visit. Owens (1985) suggests that the conflict itself is an experience which can be measured on a scale from dissatisfaction and frustration to confrontation. It may or may not regulate actual behaviour.

Following Owens (1985), we look at conflicts as a 'persistent' concept, and therefore we ask people for their general view of disturbance from other people. Opposed to many other studies (e.g. Vaske et al., 2000; Thapa and Graefe, 2003; Vaske et al., 2007) that focus on the actual encounters, we will therefore take mainly occurrence of disturbance into account. We do not get a good measure of the actual experienced conflict(s), but rather a measure of the perception of conflicts. We use crowding as an indicator for the potential of conflicts. Here we follow Jacob and Schreyer (1980) who argue that crowding is a subjective judgment of an individual that e.g. there are too many other people. So the 'too many' can refer to different number of people according to different individuals and situations. Therefore, we do not use actual numbers of visitors, but rather terms like 'Few' and 'Many'. It may be individually perceived how many 'Few' are, but the relevant measure we are looking at is how willing people are to travel to avoid the perceived crowding and thereby the potential of conflicts.

According to the literature, there are several types of conflicts among participants in similar or different types of outdoor recreation (see Manning et al., 1980, 1999 and Manning 2011 for reviews). Conflicts between users engaged in different activities (e.g., Hikers versus Mountain bikers) are known as 'out-group' conflicts whereas conflicts between participants in the same activity (e.g., hikers versus other hikers) are known as in-group conflicts (Manning, 1999). We follow this notation and identify 'in-group' as well as 'out-group' conflicts by asking people for 
their general view on disturbance from others. We use the term 'disturbance' to identify perceived conflicts. This term, disturbance, addresses the user's emotional feeling about a particular environment or situation.

\section{Methodology}

\section{2-1 choice experiment method}

The travel cost method has been widely used to value recreation since the 1960 'ies (e.g. Phaneuf and Smith, 2005, Clawson and Knetsch, 1966; Zandersen et al., 2007), and crowding has been a topic in travel cost methods (cf. reveal preference approach) since the 1970's (e.g. Cicchetti and Smith, 1976; Tratalos et al., 2013). Since the 1990'es the stated preference method choice experiment has been widely used to value environmental issues, including recreation (e.g. Adamovicz, 1998; Campbell et al., 2013).

An advantage of the stated choice experiment (CE) method compared to the travel cost method is that it allows ex ante evaluation of policies. Therefore we apply this approach and we ask respondents to choose between alternatives varying in distance from their home and amount of other forest visitors. $\mathrm{CE}$ has been used widely to value different recreational options, e.g. willingness to travel extra distance to reach better cross-country skiing conditions (Sælen and Ericson, 2013) and individual-specific preferences for recreational use of different forest types in Lorraine (Northeastern France) (Abildtrup et al. 2013). Arnberger et al. (2010) also use a choice experiment, with a latent class approach, which investigates preference heterogeneity for social conditions of urban forest visitors in Vienna and Sapporo.

Another and related advantage of stated preference studies instead of revealed travel cost is the prevention of multicollinearity in the attribute levels. Multicollinearity may be a problem because 
forests may be rather similar due to, for example, similar climatic conditions for the forest in an individual's choice set. Furthermore, the problem of endogenous attribute levels can be avoided (Hanley et al., 2002; Von Haefen and Phaneuf, 2008; Whitehead et al., 2008). If people choose their residential location based on their preferences for forest recreation, among others, the travel distance attribute will be endogenous (Parsons, 1991). Acknowledging that the actual choice of where to go for recreation is contingent upon where people live and thereby what correlated choices they have, in this study we are after what they would do if they had the option - as this may be valuable input for managers.

Travel cost studies typically use the distance travelled as input factor, and typically the willingness to travel (WTT) is used as numeraire in a choice experiment. It can be directly converted to a willingness to pay if the travel costs per kilometer can be estimated. In the current study we are mainly interested in the extra distance travelled to allow guidance for policy makers on design of recreational infrastructure. Therefore our main results are measured in terms of kilometers. But we also convert it to a measure in money in order to relate it to welfare economic studies as also Sælen and Ericson (2013) do.

\section{2-2 Data collection and survey design}

The data were collected through an internet-based questionnaire managed by the survey institute ‘Analyse Denmark' during July-August 2012. We received 1200 completed questionnaires. Respondents were asked about their motivation for going to the forest as well as their pursued activities. Respondents were also asked whether they found activities from other visitors disturbing. The questionnaire (obtainable from authors upon request) was designed using the results from two 
focus group interviews and pre-tests. Some modifications of the draft questionnaire were included based on the feedback.

The final questionnaire began with a section including questions about the frequency of visit and recreation activities respondents pursue in forests to identify different forest user groups. Then followed questions about which activities carried out by other visitors are found disturbing. Since we are examining the perceived disturbance and conflict, levels were provided in qualitative terms: 'Often', 'Sometimes', 'I meet them but they don't disturb me', and 'I never meet them'. These results are used to answer the first research question. In addition, respondents were asked if they were disturbed by people doing the same activity as them. This would address the potential of ingroup conflicts.

Subsequently, respondents were introduced to the choice experiment (CE) section where the results are used to estimate different forest user groups' WTT to avoid crowding and thereby potential conflicts.

Finally, respondents were asked follow-up questions on their socio-demographic characteristics ${ }^{1}$.

\section{2-3 Choice attributes and levels}

Each choice task consisted of two alternatives and a possibility of choosing to visit the forest or not. An example is shown in Fig. 1. The attributes of each alternative were the amount of other visitors encountered ('Few', 'Many') and the travel distance from the respondents' home to the forest (2, 5, 10, $15 \mathrm{~km}$ ). Using a nine-point Likert scale to measure crowding (e.g., Shelby et al., 1989; Jensen, 2003) is a common practice in the crowding and conflict literature. Focusing on respondents' perceptions of crowding, we chose a simpler approach and used just two levels.

\footnotetext{
${ }^{1}$ In the same questionnaire respondents received a larger CE regarding different conservation measures used for another study (see Bakhtiari et al., 2013a,b). However, as it followed the current crowding CE, we expect the WTT-results to be unaffected by that.
} 
Using eight $(2 * 4)$ alternatives all combinations were possible and they were matched to each other by using NGENE software, optimising for d-efficiency for multinomial logit modelling (Scarpa and Rose, 2008). These were divided into four blocks to give two choice tasks per respondent.

[Fig 1 should be inserted about here]

\section{2-4 Econometrics estimation}

$\mathrm{CE}$ is a stated preference technique that has been extensively used in the past decade in environmental valuation (Louviere et al., 2000; Bennett and Blamey, 2001).

The random utility model is the basis for estimation and can formally be described as:

$$
U_{i j}=V_{i j}\left(t_{j}, x_{j}, z_{i}\right)+\varepsilon_{i j}
$$

Where $U_{i j}$ is the utility of individual $\mathrm{i}$, by paying a cost equal to $\mathrm{t}$ (e.g., income tax, or in this case travel distance) to achieve the good described by alternative j. $V_{i j}$ is the deterministic part of $U_{i j}$ and depends on income; $x_{j}$, the characteristics of the good, and $z_{i}$, socio-economic characteristics of the

individual. The term ${ }^{\varepsilon_{i j}}$ is stochastic which means that its variation cannot be observed by the researcher (Train 2003). We assume it to be independent and identically distributed random variables (i.i.d.).

Assuming a linear function for $U_{i j}$ and collecting all the arguments in the vector $x_{i j}$ for alternative ${ }_{\mathrm{j}}$ and individual $i$, we can write 


$$
U_{i j}=A S C+\beta 1 * F e w+\beta 2 * \text { distance }+\varepsilon_{i j}
$$

Where $\beta$ is a vector of parameters.

The specification in equation (2) parameterises utility in preference space. Thus, the implied WTT for each attribute is the estimated ratio of the attribute's coefficient ' $\beta$ ' divided by the travel distance coefficient which is assumed to have a fixed distribution: $W T T=\beta 1 / \beta 2$. To allow for heterogeneity in the distribution of both parameters we estimate it in willingness-to-pay space (Train and Weeks, 2005), whereby the parameter estimates can be interpreted directly as the WTT to encounter 'Few' instead of 'Many' other forest visitors. Thus, the utility can be rewritten as:

$$
U=\beta 2\left[\text { distance }+\theta_{1} * A S C+\theta_{2} * \text { Few }\right]+\varepsilon
$$

Where $\theta_{i}$ is $\beta i / \beta_{2}$.

Assuming the error term $\varepsilon_{\mathrm{ij}}$ is IID extreme value distributed (see Hausmann and McFadden, 1984), the probability of choosing alternative $k$ among $j$ alternatives by individual $i$, is, according to Train (2003): 


$$
P_{i}(k)=\frac{\exp \left(\widetilde{\theta}_{i} x_{i j}\right)}{\sum_{j}^{J} \exp \left(\widetilde{\theta}_{i} x_{i j}\right)}
$$

Because we work in WTP space, we avoid the issue of scaling (see Train and Weeks, 2005).

Estimating respondents' WTT away from perceived crowding gives us the average WTT to decrease crowding in forest. In addition, we are interested in knowing the magnitude of WTT to decrease crowding for each user group that reported feeling disturbance in forests. In the survey we presented 31 statements related to forest activities (individual and group activities) and asked respondents to choose among them by answering 'Have you participated in or would you like to take part in some of the following activities within the last year, when you have visited the forest?'

Many forest visitors engage in different activities at different visits to the forest. Therefore they may fall into more than one of the above mentioned categories ( 31 presented categories). Thus, in order to avoid multicolliniarity in our model, we use factor analysis to identify those user groups which have correlation and merge them into larger groups.

\section{Results}

\section{3-1 User group attitudes for different activities in forests: 'Who disturbs whom?'}

Estimation of respondents' perceived disturbance at different levels shows that 249 out of the 1200 total interviewees $(21 \%)$ often felt disturbed by other visitors during their forest visits. In addition, 
$700(58 \%)$ indicated they have sometimes been disturbed during their visits. Only 37 (3\%) answered they were not disturbed thus far. The rest, 214 respondents (18\%), chose the option 'I don't know'.

[Figure 2 should be inserted here]

Figure 2 shows the frequency of choices of forest over distance in relation to the number of other visitors. When the distance is $2 \mathrm{~km}$, the number of respondents who chose to go to a forest with 'Few' and 'Many' visitors is very similar, but as distance increases respondents mostly chose forest with 'Few' visitors. Status quo addresses the number of respondents who chose not to visit forests and stay at home even though they were provided one of the shorter distances $(2$ or $5 \mathrm{~km})$ in their choice tasks.

[Table 1 should be inserted about here]

The result of the t-test (Table 1$)$ shows that there is no statistically significant difference $(\mathrm{p}=0.4)$ among frequency of men and women who stay at home within different age groups.

Table 2 illustrates which user groups often felt disturbed by other user groups during their visits last year. Keeping a threshold of $20 \%$ for the disturbance rate among user groups (the dark grey fields), the table shows that 'Mountain Bikers', 'Horseback riders', 'Runners', 'Group-runners', 'Dog walkers' are considered the most disturbing groups by at least two other user groups in the forests. The light grey cells in table 2 and table $\mathrm{A}$ in the appendix refer to in-group conflicts - showing that runners have the highest frequency of 'in-group' disturbance. 
[Table 2 should be inserted about here]

With regard to socio-demographic variables, results show that people in the age group 50-70 years $(p<0.05)$ felt significantly more disturbed by other people than other age classes. Likewise, men felt more disturbed by other people than women $(\mathrm{p}<0.05)$.

\section{3-2 Willingness to travel to avoid crowding and potential conflicts in forests}

To estimate WTT to avoid conflicts, we specify a utility function where different user groups are interacted with the variable 'Few' in order to identify heterogeneity in the preferences. The larger user groups/groups disturbing are the ones used, cf. Table 2.

Results of the factor analysis (Appendix, table B) of user groups show that among the categories, the groups who are 'Observing animals and plants', 'Enjoy the peace and quiet', 'Gathering mushrooms and berries', and 'Going for a walk' loaded on one factor. Thus, we merged these groups and call the new group 'Peace and nature lovers'. Also, 'Making barbeque and using stove' and 'Going for a picnic' loaded on another factor, so we merged them and called the new group 'Picnickers'. 'Running and group-running' also merged in one group called 'Exercise group'. Note that we did not include the 'Dog walker' group in our model for WTT estimation because people who go to the forest for walk cannot be distinguished of people who walk with dogs. So we merged the 'Dog walker' group with 'Going for a walk' to avoid multicolliniarity in our model.

Internal consistency of each factor was estimated using Cronbach's Alpha (Cronbach (1951) which indicates a high internal consistency, in general, values of 0.70 are recommended as the minimum level of Cronbach's alpha (Kline, 1993). 
The final utility function can therefore be written as:

$\mathrm{U}_{\mathrm{ij}}=\left(\alpha_{\mathrm{j}}+\theta_{1 \mathrm{i}}(\text { Distance })_{\mathrm{j}}+\theta_{2 \mathrm{i}}(\mathrm{Few})+\theta_{3 \mathrm{i}}(\text { Few } * \text { Mouuntain biker })_{\mathrm{j}}+\theta_{4 \mathrm{i}}(\text { Few } * \text { Peace and nature lover })_{\mathrm{j}}\right.$ $+\theta_{5 \mathrm{i}}(\text { Few } * \text { Excersise group })_{\mathrm{j}}+\theta_{6 \mathrm{i}}(\text { Few } * \text { Horserider })_{\mathrm{j}}+\theta_{7 \mathrm{i}}(\mathrm{Few} * \text { Picnicker })_{\mathrm{j}}+\theta_{8 \mathrm{i}}(\mathrm{Few} * \text { Cyclist })_{\mathrm{j}}$ $\left.+\theta_{9 \mathrm{i}}(\mathrm{Few} * \text { Overnight })_{\mathrm{j}}\right)+\varepsilon_{\mathrm{ij}}$

Distance refers to travel distance to the forest and Few addresses 'Few' visitors in the forest whom respondents meet during the visit in contrast to 'Many'.

The WTT space model is estimated through BIOGEME using 15000 iterations with the CFSQP algorithm (Bierlaire, 2003). The results in Table directly show the WTT for each attribute.

[Table 3 should be inserted here]

As seen in the table, the alternative specific constant (ASC) is significant and negative, showing respondents have a positive WTT to visit a forest rather than staying at home, regardless of the characteristics of the visit. The average marginal WTT for forests with few visitors is significant with a positive sign, showing that on average respondents are more willing to travel to be in a forest with few visitors compared to a forest with many visitors.

To analyse the differences of WTT between different user groups, we look at the interaction between each user group and the attribute few visitors. 
As seen in Table. 3, the groups 'Mountain bikers', 'Peace and nature lovers', and 'Horse riders' have an extra marginal willingness to travel (WTT) of $4 \mathrm{~km}, 4.3 \mathrm{~km}$ and $4.4 \mathrm{~km}$, respectively, in addition to the average preferred travel distance of $6 \mathrm{~km}$, to reach to a forest with 'Few' visitors. At the other end we find respondents who exercise (Exercise group) have a negative marginal WTT of a magnitude of $2 \mathrm{~km}$.

The marginal WTT for groups of 'Picnickers', 'Cyclists' and 'Overnighters' is not significantly different from the average WTT.

\section{Discussions and Conclusion}

In 2007/08 Danish forests had approximately 70 million visits by the adult (15-78 years) population (Jensen, 2012a). To set more focus on all the societal and personal benefits that visits to nature can provide, the Minister of Environment, in 2012, initiated a process to formulate a national outdoor recreation policy (Miljøministeriet, 2012). In addition, at the municipal level there have been an increasing number of policy initiatives from various administrative branches during the last decade to promote outdoor activities.

To highlight some of the present and future planning and management challenges of Danish urban forest recreation, the present study addresses the issue of perceived conflicts among different forest user groups.

We asked people for their general view of disturbance from other visitors. Contrary to many other studies (e.g. Vaske et al., 2000; Thapa and Graefe, 2003; Vaske et al., 2007) that focus on the actual encounters, we focused on the occurrence of feeling disturbances. It is therefore not a measure of the experienced conflicts, but rather a measure of the perception of conflicts. We used crowding as 
an indicator for the potential of conflicts. Here we follow Jacob and Schreyer (1980) who argue that it is an individual's subjective measure of crowding. We therefore did not use actual numbers of visitors, but rather terms like 'Few' and 'Many'. The perception of how many 'Few' constitutes may vary, but the relevant measure we are looking at is how willing people are to travel to avoid crowding and thereby the potential of conflicts.

The study identified the existence of perceived conflicts among forest user groups, where we used the presence of disturbance-feeling caused by other visitors as a measure of conflicts. It turned out that $21 \%$ of the total sample stated that they have 'often' felt disturbed either by their 'own' user group or other user group types during their last visit. This is an evidence for the presence of some kind of conflict.

Jenkins and Pigram (2013) state that there is a linkage between the importance of gender/age in leisure and outdoor recreation and the feeling of disturbance. This pattern has also been showed in our results since people in the age group $50-70$ years $(\mathrm{p}<0.05)$ felt significantly more disturbed by other people than other age classes. And men felt more disturbed than women $(\mathrm{p}<0.05)$.

Among different user groups in our sample, respondents who are categorised as 'Peace and nature lovers' expressed they felt disturbed more often than other user groups. This is in line with Stewart and Cole (2001), who found that visitors seeking solitude and silence experienced the most negative effect from disturbance due to crowding. Some visitors are more averse to crowds than others, while within the site the crowd-averse have a tendency to move furthest away from points of access (Chambers and Price, 1986). One way to avoid conflicts is to more effectively distribute people in space and time. 
Therefore, the present study using CE investigates how many additional kilometres each forest user group is willing to travel to reach a forest with 'Few' visitors as opposed to 'Many' to avoid meeting (too) many forest visitors and thereby avoid potential conflicts.

Travel distance has been chosen directly as payment vehicle, therefore respondents stated their willingness to travel, WTT, to avoid crowding and potential conflict (see Abildtrup et al., 2013; Sælen and Ericson, 2013).

To our best knowledge, this is new to the scientific literature on conflict management and recreation planning for forest. Applying a CE, the WTT further to encounter fewer visitors was estimated.

On average, respondents are willing to travel $6 \mathrm{~km}$ further to reach a forest with 'Few' visitors compared to a forest with 'Many' visitors. Assuming a total transport cost of $4 \mathrm{DKK} / \mathrm{km}$ results in $24 \mathrm{DKK} /$ visit. In general, respondents have a negative preference (WTT) for increasing travel distance. This is in line with studies by Tyrväinen (1999, 2001), Jensen and Koch (2004), and Degenhardt et al. (2011), which report the positive effect of proximity of forest on the frequency of visit. Thus, increase in travel distance will decrease preference of forest visitation.

The present study reveals that there is evidence of perceived conflicts among different forest users in Danish forests which needs to be dealt with. The study gives an overview of respondents' marginal utility to travel in order to avoid crowded forests and consequently avoid conflicts. Providing knowledge of the willingness to avoid crowding among different forest users may help managers and planners to provide recreation opportunities and distribute the visitors in line with their preferences - and by that increase the level of visitor satisfaction.

Comparison of the WTT of different user groups suggests that some groups, namely 'Mountain bikers', 'Peace and nature lovers' and 'Horseback Riders', do have a WTT further than the average 
respondent to reach a forest with fewer visitors. To support the credibility of our findings, it is worth mentioning that we defined the distance levels from zero to $15 \mathrm{~km}$. In the Danish context, for such a distance, we expect that respondents include travel with car in their preference for travelling further to find a forest with few visitors. For example, 'Mountain bikers' as well as 'Horseback riders' happen to use a car to reach the forest of interest.

In addition, we find the 'Exercise group' willing to travel less than the average travel distance to reach a less crowded forest. It can be interpreted as this group of forest users, contrary to, e.g. 'Peace and nature lovers', are more willing to meet (many) other people in the forest and do not feel as much disturbed. Also, visitors that exercise are committed to do this so many times a week, and maybe don't let their feeling of disturbance get in the way of their exercise regime. - And exercise is not exactly relaxation and peaceful.

'Picnickers' and 'Cyclists' are the ones who do not have any 'extra' travel preference than average for forests with few visitors. This is not far from our expectation. A possible interpretation is that since 'Picnickers' are mainly doing social activities, and cyclists mainly go around the forest by bike, they are not very much dependent on a specific forest site compared to 'Peace and nature lovers'.

Overall, respondents from different forest user groups preferred to travel further to reach a forest with 'Few' visitors. We identified three reaction types among different groups regarding WTT to reach a forest with few visitors. First are forest users who had larger WTT than the average which suggests that they are willing to move further to avoid others - namely 'Mountain bikers', 'Horseback riders' and 'Peace and nature lovers'. The second group includes the 'Exercise group', who were less willing to travel further than the average. This suggests that they would like/don't 
mind to meet many people during their visit, and their experience are not as affected by encounters, compared to groups like the 'Peace and nature lovers'.

The third group includes those who's WTT is not significantly different from the average WTT.

In Denmark and many other countries, there has been focus on encouraging people to go to the forest or other green spaces to exercise. And as can been seen from the results, the 'Exercise group' is not willing to travel further to avoid crowding and meeting 'Many' visitors. It can be interpreted as their needs do not require major management initiatives as their demand is relatively humble combining small (urban) forest areas and paths would be a management option to benefit this group. For groups like 'Mountain bikers', 'Horseback riders' and 'Peace and nature lovers' who are willing to bear a cost (travel further) to fulfil their needs, new forest plantations could be an option as this will increase the space and thereby potentially decrease the feeling of 'Many' visitors. Another management act will be to separate different user groups by zoning, so e.g. the 'Mountain bikers' and the 'Horseback riders' are given priority in some areas - and are excluded from others for the benefit of 'Peace and nature lovers'.

Investigating conflicts among forest user groups in different forest settings was beyond the scope of this study, but would be an area for future studies to see if forests with different characteristics such as size, tree species, topography, and facilities, will show the same WTT pattern among different forest user groups or not. 


\section{Your preferred forest to visit!}

Assume you have the option to visit forest A or forest $B$. They are identical ${ }^{*}$ in most aspects but different in terms of:

1-Number of people you meet during your forest visit

2-The distance from your home

Look at following choices (choice 1 and choice 2), which forest would you choose to visit?

\begin{tabular}{|l|l|l|c|}
\hline & Forest A & Forest B & None of these \\
\hline Number of visitors & Many visitors & Few visitors & \\
\hline $\begin{array}{l}\text { Distance from your } \\
\text { home(KM) }\end{array}$ & $5 \mathrm{KM}$ & $10 \mathrm{KM}$ & \\
\hline $\begin{array}{l}\text { Your choice (choose only } \\
\text { one option) }\end{array}$ & $\square$ & $\square$ & $\square$ \\
\hline
\end{tabular}

* Identical in terms of e.g. forest facilities and forest user types, forest covers and so on.

Figure 1: An example of a choice task given to the respondents.

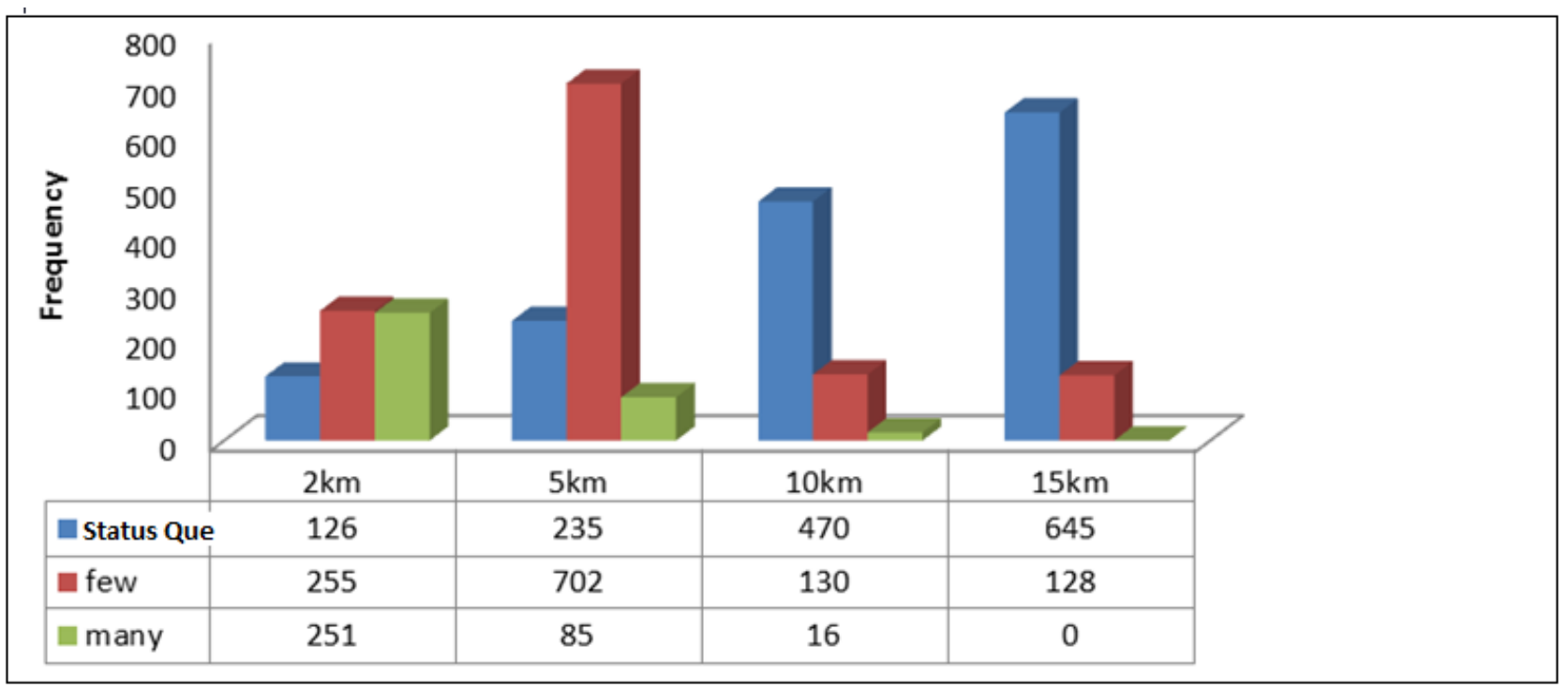

Figure 2: Distribution of forest choice in relation to number of visitors and distance 
Table 1: Characteristics of respondents who chose to stay at home despite having the option to choose minimum distance

\begin{tabular}{|c|c|c|c|c|c|c|c|}
\hline \multicolumn{8}{|l|}{ Age } \\
\hline Gender & $18-28$ & $29-39$ & $40-50$ & $51-60$ & $61-70$ & $71-99$ & Total \\
\hline Female $\%$ & 16 & 14 & 24 & 23 & 22 & 1 & 100 \\
\hline Male $\%$ & 5 & 15 & 23 & 27 & 29 & 0 & 100 \\
\hline
\end{tabular}


Table 2: Percentage of disturbing user groups and groups who often feel disturbed in the case study area during the past year.

\begin{tabular}{|c|c|c|c|c|c|c|c|c|c|c|c|c|}
\hline & \multicolumn{12}{|c|}{ Disturbing user groups } \\
\hline $\begin{array}{l}\text { Disturbed } \\
\text { Group }\end{array}$ & 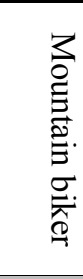 & 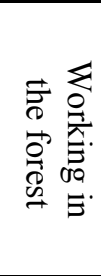 & 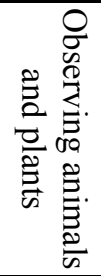 & 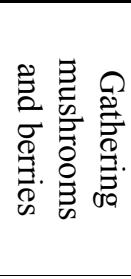 & 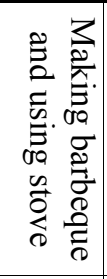 & 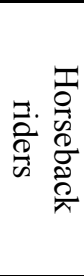 & $\begin{array}{l}\underset{\Xi}{\Xi} \\
\stackrel{\Xi}{9}\end{array}$ & 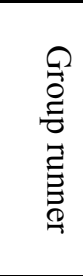 & 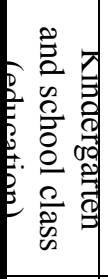 & 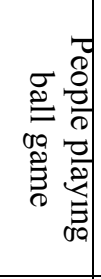 & 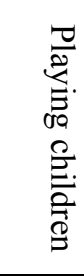 & 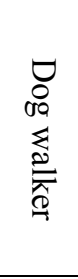 \\
\hline Mountain biker & 12.20 & 2.44 & 0.00 & 0.00 & 12.20 & 4.88 & 17.07 & 4.88 & 4.88 & 7.32 & 4.88 & 29.27 \\
\hline $\begin{array}{l}\text { Working in the } \\
\text { forest }\end{array}$ & 13.64 & 4.55 & 4.55 & 2.27 & 4.55 & 9.09 & 11.36 & 6.82 & 4.55 & 18.18 & 4.55 & 15.91 \\
\hline $\begin{array}{l}\text { Observing } \\
\text { animals } \\
\text { and plants }\end{array}$ & 21 & 1.5 & 2 & 1.5 & 4.5 & 13 & 21.5 & 20.5 & 2.5 & 2.5 & 3.5 & 21 \\
\hline $\begin{array}{l}\text { Gathering } \\
\text { mushrooms } \\
\text { and berries }\end{array}$ & 22 & 2 & 1 & 1 & 6 & 11 & 21 & 23 & 3 & 5 & 6 & 13 \\
\hline $\begin{array}{c}\text { Making } \\
\text { barbeque } \\
\text { and using stove }\end{array}$ & 10.53 & 5.26 & 10.53 & 5.26 & 0.00 & 10.53 & 15.79 & 15.79 & 5.26 & 5.26 & 5.26 & 10.53 \\
\hline $\begin{array}{l}\text { Horseback } \\
\text { riders }\end{array}$ & 30.8 & 0.0 & 0.0 & 0.0 & 7.7 & 15.4 & 7.7 & 7.7 & 0.0 & 23.1 & 0.0 & 7.7 \\
\hline Runner & 21.05 & 0.00 & 1.05 & 1.05 & 5.26 & 5.26 & 21.05 & 15.79 & 3.16 & 4.21 & 7.37 & 14.74 \\
\hline Group runner & 20.5 & 12.8 & 2.6 & 2.6 & 5.1 & 7.7 & 6.4 & 15.4 & 5.1 & 7.7 & 7.7 & 14.1 \\
\hline $\begin{array}{c}\text { Enjoying the } \\
\text { peace and quiet } \\
\text { of nature }\end{array}$ & 21.6 & 1.6 & 1.2 & 1.2 & 5.7 & 11.0 & 15.9 & 20.8 & 4.1 & 5.3 & 4.1 & 7.3 \\
\hline $\begin{array}{l}\text { Going for a } \\
\text { picnic }\end{array}$ & 22.2 & 3.7 & 2.5 & 0.0 & 7.4 & 6.2 & 23.5 & 19.8 & 2.5 & 3.7 & 8.6 & 9.9 \\
\hline Biking & 22.9 & 0.8 & 1.7 & 0.8 & 4.2 & 8.5 & 21.2 & 20.3 & 3.4 & 3.4 & 4.2 & 8.5 \\
\hline $\begin{array}{l}\text { Going for a } \\
\text { walk }\end{array}$ & 22.5 & 1.5 & 1.5 & 1.1 & 1.8 & 21.8 & 22.2 & 24.0 & 1.8 & 1.5 & 1.8 & 11.3 \\
\hline $\begin{array}{l}\text { Overnight } \\
\text { stay in the } \\
\text { forest }\end{array}$ & 10.3 & 3.4 & 3.4 & 0.0 & 0.0 & 13.1 & 13.8 & 6.9 & 3.4 & 24.1 & 3.4 & 6.9 \\
\hline Other users & 4.3 & 8.7 & 8.7 & 0.0 & 0.0 & 8.7 & 8.7 & 8.7 & 13.0 & 13.0 & 17.4 & 8.7 \\
\hline
\end{tabular}


Table 3: WTT estimates using WTT space model.

\begin{tabular}{|c|c|c|c|c|}
\hline Attributes & \multicolumn{2}{|c|}{$\begin{array}{c}\text { WTT } \\
\text { (confidence interval) } \\
\text { (km/visit) }\end{array}$} & Standard error & $\begin{array}{c}\text { WTP }^{\mathrm{a}} \\
\text { (DKK/Visit) }\end{array}$ \\
\hline \multirow{2}{*}{ Few visitor } & $\beta$ & $\begin{array}{c}6^{* * *} \\
(5.09 ; 6.09) \\
\end{array}$ & $0.05^{* * *}$ & 24 \\
\hline & $\sigma$ & $0.005^{* * *}$ & $0.08^{* * *}$ & - \\
\hline \multirow[t]{2}{*}{ Distance } & $\beta$ & $-1.07 * * *$ & $0.05^{* * *}$ & - \\
\hline & $\sigma$ & $0.2 * * *$ & $0.1^{* * *}$ & - \\
\hline$A S C$ & $\beta$ & $\begin{array}{c}-2.13 * * * \\
(-2.28 ;-1.97)\end{array}$ & $0.08 * * *$ & - \\
\hline few $*$ Mountain biker & $\beta$ & $\begin{array}{c}4^{* * *} \\
(1.64 ; 6.35)\end{array}$ & $1.2 * * *$ & 24 \\
\hline few * Peace and nature lovers & $\beta$ & $\begin{array}{c}4.3 * * * \\
(3.22 ; 5.37)\end{array}$ & $0.55^{* * *}$ & 25.2 \\
\hline few $*$ Exercise group & $\beta$ & $\begin{array}{c}-2 * * * \\
(-0.94 ;-3.05)\end{array}$ & $0.54 * * *$ & -10 \\
\hline few $*$ Horseback rider & $\beta$ & $\begin{array}{c}4.4 * * * \\
(0.87 ; 7.93)\end{array}$ & $1.8 * * *$ & 28.4 \\
\hline few * Picnicker & $\beta$ & 0.3 & 0.6 & 1.2 \\
\hline few * Cyclist & $\beta$ & 0.04 & 0.5 & 0.8 \\
\hline few *Overnighters & $\beta$ & 2.4 & 0.1 & 0.16 \\
\hline$A I C / N$ & \multicolumn{3}{|c|}{1.2} & \\
\hline$\rho 2$ & \multicolumn{3}{|c|}{0.44} & \\
\hline$L L$ & \multicolumn{3}{|c|}{-2031} & \\
\hline$N$ & \multicolumn{3}{|c|}{1200} & \\
\hline
\end{tabular}

a The monetary value of WTT estimation is based on the total transport cost per $\mathrm{km}$ in Denmark which is $4 \mathrm{DKK} / \mathrm{km}(1 \mathrm{DKK}=$ 0.18 USD): (Federation of Danish Motorists - FDM). 
Appendix I.

Table A: Total number of disturbing user groups and groups who often feel disturbed in the case study area during the past year.

\begin{tabular}{|c|c|c|c|c|c|c|c|c|c|c|c|c|c|}
\hline & \multicolumn{13}{|c|}{ Disturbing user groups } \\
\hline Disturbed Group & 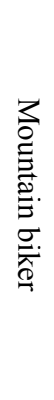 & 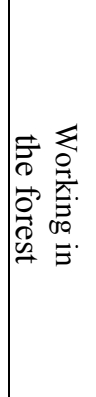 & 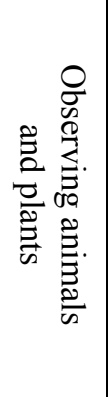 & 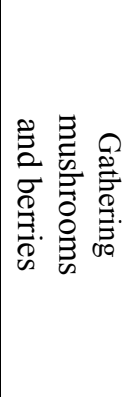 & 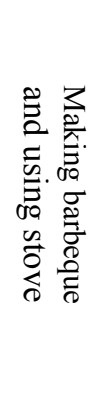 & 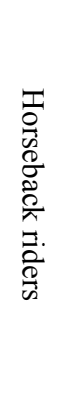 & 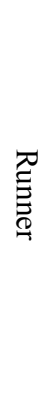 & 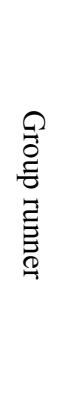 & 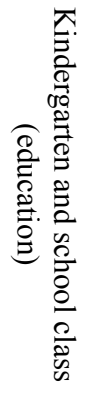 & 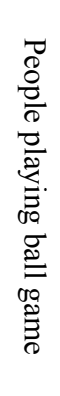 & 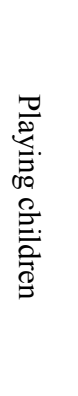 & 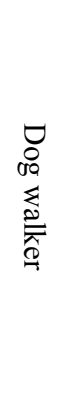 & $\underset{\underline{D}}{\stackrel{1}{O}}$ \\
\hline Mountain biker & 5 & 1 & 0 & 0 & 5 & 2 & 7 & 2 & 2 & 3 & 2 & 12 & 43 \\
\hline Working in the forest & 6 & 2 & 2 & 1 & 2 & 4 & 5 & 3 & 2 & 8 & 2 & 7 & 48 \\
\hline $\begin{array}{l}\text { Observing animals } \\
\text { and plants }\end{array}$ & 42 & 3 & 4 & 3 & 9 & 26 & 43 & 41 & 5 & 5 & 7 & 32 & 210 \\
\hline $\begin{array}{l}\text { Gathering mushrooms } \\
\text { and berries }\end{array}$ & 22 & 2 & 1 & 1 & 6 & 11 & 21 & 23 & 3 & 5 & 6 & 13 & 108 \\
\hline $\begin{array}{l}\text { Making barbeque } \\
\text { and using stove }\end{array}$ & 2 & 1 & 2 & 1 & 0 & 2 & 3 & 3 & 1 & 1 & 1 & 2 & 20 \\
\hline Horseback riders & 4 & 0 & 0 & 0 & 1 & 2 & 1 & 1 & 0 & 3 & 0 & 1 & 15 \\
\hline Runner & 20 & 0 & 1 & 1 & 5 & 5 & 20 & 15 & 3 & 4 & 7 & 14 & 100 \\
\hline Group runner & 10 & 10 & 2 & 2 & 4 & 6 & 5 & 12 & 4 & 6 & 6 & 11 & 68 \\
\hline $\begin{array}{l}\text { Enjoying the peace and } \\
\text { quiet of nature }\end{array}$ & 53 & 4 & 3 & 3 & 14 & 27 & 39 & 51 & 10 & 13 & 10 & 18 & 255 \\
\hline Going for a picnic & 18 & 3 & 2 & 0 & 6 & 5 & 19 & 8 & 2 & 3 & 7 & 8 & 86 \\
\hline Biking & 27 & 1 & 2 & 1 & 5 & 10 & 25 & 24 & 4 & 4 & 5 & 10 & 122 \\
\hline Going for a walk & 62 & 4 & 4 & 3 & 5 & 60 & 61 & 31 & 5 & 4 & 5 & 31 & 306 \\
\hline Overnight stay in the forest & 3 & 1 & 1 & 0 & 0 & 7 & 4 & 2 & 1 & 7 & 1 & 2 & 32 \\
\hline Other users & 1 & 2 & 2 & 0 & 0 & 2 & 2 & 2 & 3 & 3 & 4 & 2 & 24 \\
\hline
\end{tabular}


Table B: Statements related to the forests activities pursued in forests and activities which disturb visitors. Principal component analysis, varimax rotation.

\begin{tabular}{|c|c|c|c|c|}
\hline \multirow{14}{*}{ 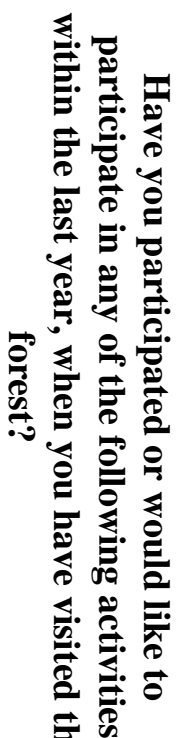 } & Activities & Factor1 & Factor 2 & Factor 3 \\
\hline & Overnight stay & - & - & \\
\hline & Observing animals and plants & 0.5292 & - & - \\
\hline & $\begin{array}{l}\text { Gathering mushrooms } \\
\text { and berries }\end{array}$ & 0.5192 & - & - \\
\hline & Going for a picnic & - & 0.5102 & - \\
\hline & Enjoying the peace and quiet of nature & 0.5945 & - & - \\
\hline & Biking & - & - & \\
\hline & Horseback riding & - & - & - \\
\hline & $\begin{array}{l}\text { Kindergarten and school class } \\
\text { (education) }\end{array}$ & - & - & - \\
\hline & Group-running & & & 0.5232 \\
\hline & Walking & 0.5000 & - & - \\
\hline & Mountain biking & - & - & - \\
\hline & Making barbeque and using stove & - & 0.5102 & - \\
\hline & $\begin{array}{l}\text { Working in } \\
\text { the forest }\end{array}$ & - & - & \\
\hline & Running & & & 0.5421 \\
\hline
\end{tabular}

\section{Acknowledgements}

The authors are grateful to the Forest and Nature for Society programme (FONASO), which funded the current study. FONASO is part of the Erasmus Mundus programme initiated by the European Commission. We wish to acknowledge the valuable help provided by professor emeritus Finn Helles for the language revision of the present paper. 


\section{References}

Abildtrup, J., Albers, H., Stenger-Letheux, A., Termansen, M. ,2013. Scale, location, and spatial interactions in the analysis of natural resources: lessons for forest economics. Ecological Economics, 92, 34-36.

Absher, J. D., Lee, R. G.,1981. Density as an incomplete cause of crowding in backcountry settings. Leisure Sciences 4(3), 231-247.

Adamowicz, W., Boxall,P., Williams,M., Louviere, J.,1998. Stated preference approaches for measuring passive use values: choice experiments and contingent valuation. American journal of agricultural economics $80(1), 64-75$.

Arnberger, A., Haider,W., 2005. Social effects on crowding preferences of urban forest visitors. Urban Forestry \& Urban Greening 39(2), 345-365.

Arnberger, A., Haider,W., 2007. Acomparision of global and actual measures of perceived crowding of urban forest visitors. Journal of leisure Research 3(3), 125-136.

Arnberger, A., Mann, C., 2008. Crowding in European forests: a review of recent research and implications for forest management and policy. Forestry 81(4), 599-571.

Arnberger, A., Aikoh, T., Eder, R., Shoji, Y., Mieno, T., 2010. How many people should be in the urban forest? A comparison of trail preferences of Vienna and Sapporo forest visitor segments. Urban Forestry \& Urban Greening 9, 215-225.

Bakhtiari, F., Lundhede,T., Gibbons, J., Strange, N., Jacobsen. J.,2013. How should biodiversity be presented in valuation studies? Testing for embedding and information bias. Submited to the journal of Forest economics.

Bakhtiari, F., Jacobsen, J. B., Thorsen, B. J., Lundhede, T. H., Strange, N., Boman,M., Gibbons, J., 2013. Valuation of biodiversity protection across borders: Limits to the public good? Submited to the Journal of Environmental and Resource Economics.

Bell, S., Tyrväinen, L., Sievänen, T., Pröbstl, U., Simpson M., 2007. Outdoor Recreation and Nature Tourism: A European Perspective, Living Rev. Landscape Research 1, 1-46.

Bennett, J., Blamey, R., 2001. The Choice Modelling Approach to Environmental Valuation. Edward Elgar Publishing Limited.

Campbell, D., Vedel,S.E., Thorsen, B.J., Jacobsen, J.B., 2013. Heterogeneity in the WTP for recreational access: distributional aspects. Journal of Environmental Planning and Management. 1200-1219.

Chambers, T. W. M., Price, C., 1986. Recreational congestion: some hypotheses tested in the forest of Dean. Rural Studies 2(1), 41-52.

Cicchetti, C.J.,Smith, V.K.,1976. The cost of congestion. Cambridge, MA:Ballinger.

Clawson, M., Knetsch,J.L., 1966. Economics of Outdoor Recreation. Resources for the Future: Washington, D.C.

Clemmensen, T. J., Daugaard, M. and Nielsen, T., 2010. Quali fying Urban Landscapes. JoLA 5/2: 24-39. 
Cronbach, L.J.,1951. Coefficient alpha and the internal structure of tests. Psychometrika. 16, 297-334.

Danish Forest and Nature Agency, 2002. The Danish national forest programme in an international perspective. Ministry of Environment, Division of Forest Policy of the Danish Forest and Nature Agency, Denmark.

Danish Forest and Nature Agency., 2009. Friluftskortet (overview of recreational facilities etc. in Danish state forests). Http://friluftskortet.dk . Accessed 2 April 2009.

Degenhardt, B., Frick, J. Buchecker, M., Gutscher, H., 2011. Influences of personal, social, and environmental factors on workday use frequency of the nearby outdoor recreation areas by working people. Leisure Science 33, 420-440.

Federation of Danish Motorists in Denmark (FDM), 2009: http://jyllandsposten.dk/motor/ECE4083757/din-bil-koster-dig-3-76-kr-per-kilometer/

Grahn, P., Stigsdotter, U., 2003. Landscape Planning and Stress. Urban Forestry \& Urban Greening 2, 1-18.

Hall, T., Cole D., 2007. Changes in the motivations, Perception and Behaviors of Recreation Users:

Displacement and Coping in Wilderness. RMRS-RP-63. Department of Agriculture- Forest Service Rocky Mountain Research Station, Fort Collins, Colorado, USA.

Hall, T. E., Shelby, B., 2000. Temporal and spatial displacement: Evidence from a high use reservoir and alternate sites. Journal of Leisure Research 32, 435-456.

Hanley, N., Wright, R.E., Koop, G., 2002. Modelling recreation demand using choice experiments: rock climbing in Scotland. Environmental and Resource Economics 22, 449-466.

Hammitt, W. E., Schneider, I. E., 2000. Recreation conflict management. In Trends in Outdoor Recreation, Leisure and Tourism, edited by W. C. Gartner and D. W. Lime, 347-356. New York: CABI Publishing.

Hammitt, W. E., Patterson, M., 1991. Coping behaviours to avoid visitor encounters: Its relationship to wild land privacy. Journal of Leisure Research 23(3), 225-237.

Hausman, J., McFadden, D.,1984. Specication Tests for the Multinomial Logit Model. Econometrica 52(5), 1219-1240.

Inglis, G.,Johnson, V. and Ponte, F.1999. Crowding norms in marine settings: a case study of snokeling on the Great Barrier Reef.Environmental Management. 24, 369-381.

Jacobsen, J. B., Lundhede, T. H., Thorsen, B. J., 2012. Valuation of wildlife populations above survival. Biodiversity Conservation 21, 543-563.

Jacob, G., Schreyer, R., 1980. Conflict in outdoor recreation: A theoretical perspective. Journal of Leisure Research 12, 368-380.

Jenkins, J., Pigram, J., 2013. Encyclopedia of Leisure and Outdoor Recreation. Routledge.

Jensen, F.S., 1999. Forest Recreation in Denmark from the 1970s to the 1990s. Forskningsserien nr. 26, Forskningscentret for Skov \& Landskab, Hørsholm. 
Jensen, F.S., 2003. Friluftsliv i 592 skove og andre naturområder. Skovbrugsserien nr. 32, Forskningscentret for Skov \& Landskab, København.

Jensen, F.S., Koch, N.E., 2004. Twenty-five Years of Forest Recreation Research in Denmark and its Influence on Forest Policy. Scandinavian Journal of Forest Research 19(4), 93-102.

Jensen, F.S., 2006. Crowding in Danish Forests - a Nonexistent Problem? In: Siegrist, D., Clivaz, C., Hunziker, M., Iten, S. (Eds.) Exploring the Nature of Management. Proceedings of the Third International Conference on Monitoring and Management of Visitor Flows in Recreational and Protected Areas.University of Applied Sciences, Switzerland, 13-17 September 2006.

Jensen, F.S., 2012a. Friluftsliv i skovene 2008 (2). Antal skovbesøg pr. år. Videnblade Planlægning og Friluftsliv, nr. 6.1-65. Skov \& Landskab, Frederiksberg.

Jensen, F.S., 2012b. Friluftsliv i skovene 2008 (8). Transportafstand. Videnblade Planlægning og Friluftsliv, nr. 6.1-72. Skov \& Landskab, Frederiksberg.

Johnson, A., Dawson, C., 2004. An exploratory study of the complexities of coping behavior in Adirondack wilderness. Leisure Science 26, 281-293.

Kline, P., 1993. The handbook of psychological testing, London: Routledge.

Kleiber, O., 2001. Valuation of recreational benefits and visitor conflicts in an urban forest. Fifth International Conference of the International Society for Ecological Economics (ISEE), Moscow, Russia.

Konijnendijk, C. C., 2008. The Forest and the City (Berlin: Springer Verlag).

Kuss, F., Graefe, A., Vaske, J.,1990. Visitor impact management: A review of research. National Parks and Conservation Association, Washington D.C.:

Louviere, J.J., Hensher, D.A., Swait J., 2000. Stated choice methods and applications. Cambridge University Press, New York.

Maas, J., Verheij, R.A., Groenewegen, P.P., De Vries, S., Spreeuwenberg, P .,2006. Green space, urbanity, and health: how strong is the relation? Journal of Epidemiology and Community Health 60(7), 587-592.

Manning, R., Valliere, W,Wang, B., 1999. Crowding norms: Alternative measurement approaches. Leisure Sciences 21( 2), 97-115.

Manning, R., 2011. Studies in Outdoor Recreation: Search and Research for Satisfaction (3rd Edition). Oregon State University Press, Corvallis, OR. Oregon State Univesity Press, 468pp.

Manning, R.E., Ciali. C.P., 1980. Recreation density and user satisfaction: a further exploration of the satisfaction model. Journal of Leisure Research 12, 329-345.

Miljøministeriet, 2012: Ny national friluftspolitik.

http://www.naturstyrelsen.dk/Naturoplevelser/Ny_friluftspolitik/

Owens, P. L. 1985. Conflict as a Social Interaction Process in Environment and Behaviour Research: The Example of Leisure and Recreational Research. Journal of Environmental Psychology 5, 243-259.

Olsen, B.S., Bonnichsen, O., Laugesen, M.f.,Dubgaard, A.,Thorsen, B.J., 2013. Adgang til grønne områder, fysisk aktivitetsniveau og sundhed Er der evidens for en sammenhæng, der kan vurderes

samfundsøkonomisk? Ifro rapport 217. Institut for Fødevare- og Ressourceøkonomi Københavns Universitet. 
Parsons, G.R., 1991. A note on choice of location in residential travel cost demand models. Land Economics 67 (3), 360-364.

Phaneuf, D. J., Smith, V. K., 2005. Recreation demand models. In K. G. Mäler \& J. R. Vincent (Eds.), Handbook of Environmental Economics 671-761.Amdsterdam: Elsevier B.V.

Rapoport, A., 1975. Toward a Redefinition of Density. Environment and Behavior 1, 133-158.

Stenar, M., 2012. Spids konfrontation - cyklister sætter liv og førlighed på spil. Skoven 44, 294-295.

Scarpa, R., Thiene, M., Train, K., 2008. Utility in willingness to pay space: a tool to address confounding random scale effect in destination choice to the Alps.Journal of Agricultural Economics 90(4), 994-1010.

Shelby, B., Vaske, J.J., Heberlein, T.A., 1989. Comparative analysis of crowding in multiple locations: results from fifteen years of research. Leisure Sciences 11, 269-291.

Stewart, W.P., Cole, D.N., 2001. Number of encounters and experience quality in Grand Canyon Backcountry: Consistently negative and weak relationships. Journal of Leisure Research. 33(1), 106-120.

Stokols, D.,1972. On the distinction between density and crowding: Some implications for future research. Psychological Review 79, 275-277.

Sælen, H., Ericson. T., 2013. The recreational value of different winter conditions in Oslo forests: A choice experiment. Journal of Environmental Management, 2013, Vol.131, pp.426-434

Søderlund. K., 2012. Flere søm i skovbunden. Skoven 44, 478-479.

Thapa, B., Graefe, A. R.,2003. Level of skill and its relationship to recreation conflict and tolerance among adult skiers and snowboarder. World Leisure Journal 45(1), 13-25.

Train, K.E., 2003. Discrete Choice Methods with Simulation. Cambridge University Press, Cambridge.

Train,K., Weeks, M., 2005. Discrete Choice Model in Preference Space and Willing to Pay space. In: Scarpa; R., Alberini, A., (Eds),Application of Simulation Methods in Environmental and Resource Economics. Springer Publisher, Dordrecht, The Netherlands, pp.1-16.

Tratalos, J., Sugden, R., Bateman, I., Gill, J., Jones, A., Showler, D., Sutherland, W., Watkinson, A.,2013. The Conflict Between Conservation and Recreation When Visitors Dislike Crowding: A Theoretical and Empirical Analysis of the Spatial Distribution of Recreational Beach Users. Environmental and Resource Economics 55(3), 447-465.

Tyrväinen, L.,1999. Monetary valuation of urban forest amenities in Finland. Academic dissertation. Finnish Forest Research Institute, Research papers 739. Finnish Forest Research Institute, Vantaa.

Tyrväinen, L., 2001. Use and valuation of urban forest amenities in Finland. Journal of Environmental Management 62,75-92. 
Vaske, J.J., Carothers, P., Donnelly, M.P., Baird, B., 2000. Recreation conflict among skiers and snowboarders. Leisure Sciences 22,297-313.

Vaske, J.J. , Donnelly, M.P. and Lehto , X. 2002 Visitor crowding and normative tolerances at congested areas of Rocky Mountain National Park . Human Dimensions of Natural Resources Unit Report, 50 . Colorado State University, Fort Collins, CO .

Vaske, J. J., Needham, M. D., Cline Jr., R. C., 2007. Clarifying interpersonal and social values conflict among recreationists. Journal of Leisure Research 39, 182-195.

Vedel, S.E., Thorsen, B.J., Jacobsen, J.B.,2009. First-movers, non-movers, and social gains from subsidizing entry in markets for nature-based recreational goods . Ecological Economics 68,2363-2371.

Vedel, S.E., 2010. Economic incentives for provision of environmental goods and services from forest and natural areas. PhD thesis, University of Copenhagen, Denmark.

Von Haefen, R.H., Phaneuf, D.J., 2008. Identifying demand parameters in the presence of unobservables: a combined revealed and stated preference approach. Journal of Environmental Economics and Management $56(1), 19-32$.

Whitehead, J.C., Pattanayak, S.K., Van Houtven, G.L., Gelso, B.R., 2008. Combining revealed and stated preference data to estimate the nonmarket value of ecological services: an assessment of the state of the science. Journal of Economic Surveys 22 (5), 872-908.

Zandersen, M., Termansen, M. Jensen, F. S., 2007. Evaluating approaches to predict recreation values of new forest sites. Journal of Forest Economics, 13; 103-128. 